\title{
Pola Asuh Orang Tua Terhadap Motivasi Belajar Peserta Didik Pada Masa Pandemic Covid-19
}

\author{
Sri Widyastuti, Rintis Rizkia Pangestika, Nur Ngazizah \\ Universitas Muhammadiyah Purworejo, Indonesia \\ *Coresponding Author: sriwidyastuti2507@gmail.com
}

Article History:

Received 2021-08-28

Revised 2021-12-18

Accepted 2022-01-17

DOI:

10.31949/educatio.v8i2.1446

\begin{abstract}
The COVID-19 pandemic has had an impact on changes in the education sector, one of which has to be done online. This of course makes students' learning motivation while at home without supervision from the teacher, therefore the intervention of parenting is important in student learning. This study aims to determine the distribution of parenting patterns to students and to describe parenting patterns during the COVID-19 pandemic on students' learning motivation. The data collection method used is the Miles and Huberman method. This study uses a qualitative method, with a descriptive approach. Subject taking technique using saturated sampling. The number of respondents studied were 15 students and their parents. Data analysis techniques in this study include data reduction, data presentation, data verification and drawing conclusions. Data collection techniques are questionnaires, interviews, and documentation. The results of the research from the description of parenting patterns on the learning motivation of students are that there are two parenting styles that are applied, namely democratic and permissive. The parenting pattern consists of democratic parenting and permissive parenting. It can be seen from the results of the percentage showing that democratic parenting is $86.67 \%$ and permissive parenting is $13.33 \%$. The factors that trigger the lack of learning motivation of students consist of: intelligence factors and technological factors, namely games. It can be seen from the percentage of students with good motivation of $73.33 \%$ and students with less motivation of $26.67 \%$. This shows that democratic parenting affects students' learning motivation.
\end{abstract}

Keywords: learning motivation; parent; parenting

\section{Abstrak}

Pandemi covid-19 telah memberikan dampak perubahan terhadap bidang pendidikan, salah satunya pembelajaran terpaksa dilakukan secara daring. Hal ini tentunya menjadikan motivasi belajar peserta didik selama di rumah tanpa pengawasan dari guru, maka dari itu campur tangan pola asuh orang tua menjadi penting dalam pembelajaran peserta didik. Penelitian ini bertujuan untuk mengetahui sebaran pola asuh orang tua terhadap peserta didik dan mendeskripsikan pola asuh orang tua pada masa pendemi covid-19 terhadap motivasi belajar peserta didik. Metode pengumpulan data yang digunakan adalah metode Miles and Huberman. Penelitian ini menggunakan metode kualitatif, dengan pendekatan deskriptif. Teknik pengambilan subjek menggunakan sampling jenuh. Jumlah responden yang diteliti adalah 15 peserta didik dan orang tuanya. Teknik analisis data dalam penelitian ini meliputi reduksi data, penyajian data, verifikasi data dan menarik kesimpulan. Teknik pengumpulan data yaitu angket, wawancara, dan dokumnetasi. Hasil penelitian dari deskripsi pola asuh orang tua terhadap motivasi belajar peserta didik yakni terdapat dua pola asuh yang diterapkan yaitu demokratis dan permisif. Pola asuh tersebut terdiri dari pola asuh demokratis dan pola asuh permisif. Terlihat dari hasil presentase yang menunjukkan pola asuh demokratis sebesar $86,67 \%$ dan pola asuh permisif sebesar $13,33 \%$. Faktorfaktor yang menjadi pemicu kurangnya motivasi belajar peserta didik terdiri dari: faktor intelegensi dan faktor teknologi yaitu game. Terlihat dari presentase siswa dengan motivasi baik sebesar $73,33 \%$ dan siswa dengan motivasi kurang sebesar $26,67 \%$. Hal ini menunjukkan bahwa pola asuh demokratis mempengaruhi motivasi belajar peserta didik.

Kata Kunci: motivasi belajar; orang tua; pola asuh 


\section{PENDAHULUAN}

Kegiatan belajar mengajar yang terjadi di sekolah bersama dengan guru diharapkan dapat mencapai tujuan pembelajaran yang sudah direncanakan. Peserta didik menjadi audience yang siap menerima informasi dari guru sebagai fasilitator. Kegiatan pembelajaran yang terjadi di sekolah masih dalam pengawasan dari guru, sehingga peserta didik akan tetap terbimbing dan terawasi. Berbeda halnya dengan ketika mereka belajar di rumah maka hanya kelurga khususnya orang tua yang akan bertanggung jawab penuh terhadap anaknya karena orang tua adalah guru utama dan pertama bagi anak (Fadhilah et al, 2019). Pandemi covid-19 telah memberikan dampak dalam berbagai bidang termasuk salah satunya adalah bidang pendidikan. Pada masa pandemi covid-19 pembelajaran terpaksa dilakukan secara daring dikarenakan untuk menekan angka penularan virus. Hal ini tentunya akan berdampak pada motivasi belajar peserta didik selama di rumah tanpa pengawasan dari guru, maka dari itu campur tangan pola asuh orang tua menjadi penting dalam pembelajaran peserta didik. Pembelajaran daring akan berjalan secara efektif apabila peserta didik berperan aktif dalam proses pembelajaran dan memiliki motivasi untuk belajar selama di rumah. Orang tua yang terlalu sibuk dengan urusan ataupun pekerjaan mereka sendiri tanpa memperhatikan tumbuh kembang dan pendidikan anaknya akan menimbulkan ketidakberhasilan anak dalam proses pembelajaran. Motivasi belajar anak berkaitan erat dengan sejauh mana orang tua memberikan dukungan dan dorongan untuk kemajuan belajar anaknya.

Pembelajaran daring merupakan pembelajaran menggunakan jaringan internet yang dapat digunakan secara jarak jauh dengan aksesibilitas, konektivitas, fleksibilitas, kemampuan untuk memunculkan interaksi pembelajaran baik dengan dampak positif maupun negatif (Gusti, 2020; Hamidi, 2020; Hayati, 2020). Hal ini membuat proses pembelajaran terjadi kurang efektif, pembelajaran lebih banyak terjadi di rumah. Motivasi belajar artinya alasan seseorang belajar atau adanya dorongan seseorang melakukan perbuatan belajar baik yang muncul dari dalam dirinya sendiri ataupun dari orang lain (Umam, 2019; Utomo, 2015). Motivasi belajar seseorang dapat kita lihat dan amati dari tingkah laku seseorang mengenai seberapa jauh kemauannya untuk mencapai tujuan dalam pembelajaran.

Keluarga memiliki peran penting dalam menumbuhkan dan mendorong munculnya motivasi seseorang untuk mencapai tujuan tertentu. Jika motivasi belajar peserta didik rendah maka akan berdampak pada hasil belajar peserta didik yang rendah pula. Sebaliknya jika motivasi belajar peserta didik tinggi maka hasil belajar yang akan diperoleh juga menjadi maksimal. Oleh karena itu orang tua merupakan faktor pertama dan paling penting dalam mendidik anak. Menurut Kurniawan (2016) pola asuh orang tua dapat didefinisikan sebagai gambaran tentang sikap dan perilaku orang tua terhadap anak dalam berinteraksi, berkomunikasi, bimbingan selama kegiatan pengasuhan. Interaksi antara anak dan orang tua bisa diwujudkan dengan cara memberikan perhatian dan kasih sayang. Terutama bagi peserta didik sekolah dasar yang masih sangat memerlukan dorongan dari keluarga. Motivasi belajar anak berkaitan erat dengan sejauh mana orang tua memberikan dukungan dan dorongan untuk kemajuan belajar anaknya.

Hasil wawancara dengan guru kelas V di MI Al-Huda Kebonsari yaitu terdapat beberapa masalah diantaranya; 1) Motivasi belajar peserta didik masih banyak yang kurang karena kesadaran untuk membaca dan memahami materi kembali masih kadang anak merasa malas karena tidak ada pengawasan dari guru secara langsung; 2) Selain itu anak kurang memiliki motivasi karena penguasaan materi yang kurang, sehingga tidak paham dengan materi yang diberikan; 3) Beberapa orang tua yang disibukkan dengan pekerjaan sehingga kurang memperhatikan belajar anak selama di rumah; 4) pola asuh yang diterapkan orang tua berbeda-beda dan memiliki kontribusi yang berbeda pula pada motivasi belajar anak; 5) anak tidak mau mengerjakan tugas sehingga orang tua yang mengerjakan tugas dari sekolah; 6) faktor penghambat pembelajaran daring yaitu jumlah ponsel yang terbatas dalam keluarga, sinyal dan kuota internet. Berdasarkan permasalahanpermasalahan di atas, maka perlu dilakukan penelitian terkait pola asuh orang tua terhadap motivasi belajar peserta didik selama pandemi Covid-19. Menurut Kurniawan (2016) pola asuh orang tua terhadap anak dibedakan menjadi tiga. Pertama, pola asuh permisif adalah jenis pola pengasuhan anak yang acuh tak acuh, tidak perduli, bahkan masa bodoh terhadap anak. Kedua, pola asuh otoriter adalah pola pengasuhan anak 
yang bersifat pemaksaan, keras, dan penuh aturan dimana orang tua akan membuat banyak aturan atau tekanan yang harus dipatuhi oleh anak-anaknya tanpa mau tahu perasaan sang anak. Ketiga, pola asuh demokratis yakni pola pengasuhan orang tua pada anak yang memberikan kebebasan dalam arti positif pada anak untuk berkreasi dan mengeksplorasi banyak hal sesuai dengan kemampuan anak dengan batasan dan pengawasan yang baik dari orang tua. Pola asuh yang diberikan orang tua pada anak berbeda-beda, tentunya hasil yang akan berdampak pada anak juga berbeda. Hal ini dibuktikan dalam penelitian Saputri et al (2019) menunjukkan hasil perhatian orang tua dan motivasi memiliki korelasi dengan hasil belajar. Motivasi yang diterapkan orang tua memiliki rata-rata $83 \%$. Peserta didik memiliki hasil belajar yang baik dengan rata-rata $50 \%$ ke atas.

Berdasarkan latar belakang di atas penelitian ini bertujuan untuk mengetahui jenis dan sebaran pola asuh orang tua terhadap peserta didik kelas V MI Al-Huda Kebonsari dan mendeskripsikan pola asuh orang tua pada masa pendemi covid-19 terhadap motivasi belajar peserta didik.

\section{METODE PENELITIAN}

Metode penelitian yang dilakukan adalah metode penelitian kualitatif. Jenis penelitian yang digunakan dalam penelitian ini adalah interaktif. Metode interaktif digunakan dalam penelitian prosesnya tidak harus terstruktur. Metode penelitian yang digunakan dalam penelitian ini dimaksudkan untuk mengetahui atau memperoleh informasi mengenai pola asuh orang tua terhadap motivasi belajar siswa. Penelitian dilakukan di MI Al-Huda Kebonsari, Kecamatan Purwodadi, Kabupaten Purworejo. Populasi dalam penelitian ini adalah siswa, orang tua siswa, guru kelas V. Data populasi terdiri dari 15 siswa dan 15 orang tua siswa serta satu guru kelas V. Sampel pada penelitian ini menggunakan teknik sampling jenuh untuk pengambilan sampel. Penelitian ini bertujuan untuk mengetahui pola asuh orang tua terhadap motivasi belajar siswa kelas V. Pengambilan sampel pada penelitian ini diambil dari guru kelas V, siswa dan semua orang tua siswa kelas V MI Al-Huda Kebonsari.

Pengumpulan data yang digunakan 1) Angket, pada penelitian ini angket diberikan kepada siswa dan orang tua siswa kelas V MI Al-Huda Kebonsari. Angket berisi tentang pola asuh orang tua dan motivasi belajar siswa. Angket yang digunakan penelitian ini adalah angket tertutup. 2) wawancara merupakan salah satu bentuk teknik pengumpulan data yang banyak digunakan dalam penelitian deskriptif kualitatif dan deskriptif kuantitatif (Syukmadinata, 2012). Wawancara yang dilakukan peneliti digunakan untuk mendapat informasi yang berkenaan dengan pola asuh orang tua. Pada saat melakukan wawancara, selain membawa instrumen sebagai pedoman wawancara juga menggunakan alat bantu berupa alat perekam suara untuk mendukung kegiatan wawancara. Pada penelitian ini peneliti mewawancarai guru kelas, dan orang tua siswa kelas V MI Al-Huda Kebonsari. 3) dokumentasi, peneliti menggunakan hamphone atau ponsel untuk memudahkan dalam mengumpulkan data dokumentasi untuk mendukung dan menguatkan data yang dikumpulkan. Dokumentasi digunakan peneliti untuk memperkuat angket, wawancara dan observasi. Melalui dokumentasi, peneliti juga dapat mengetahui bahwa data yang diambil sebelumnya adalah akurat.

\section{HASIL DAN PEMBAHASAN}

Berdasarkan penelitian yang telah peneliti lakukan berikut hasil pembahasan yang diperoleh:

\section{Persebaran Pola Asuh Orang Tua}

Persebaran mengenai pola asuh orang tua yang telah diterapkan di MI Al-Huda Kebonsari, diperoleh berdasarkan hasil pengumpulan data angket orang tua dan wawancara. Hasil tersebut, peneliti menemukan dua pola asuh yang sebelumnya ada tiga pola asuh orang tua yang menjadi fokus penelitian. Dua pola asuh yang ditemukan yaitu pola asuh demokratis dan pola asuh permisif. Pola asuh demokratis menjadi pola asuh yang paling banyak diterapkan oleh orang tua siswa kelas V MI Al-Huda Kebonsari. Sebanyak 13 orang tua yang menerapkan polas asuh demokratis, 2 pola asuh permisif dan tidak menemukan adanya pola asuh otoriter. Sedangkan untuk motivasi belajar siswa terdapat 11 siswa dengan tingkat motivasi belajar baik, 4 
siswa dengan motivasi belajar kurang. Pada pola asuh demokratis yang diterapkan oleh 13 orang tua siswa terdapat dua siswa dengan kategori belajar kurang. Dua orang tua dengan pola asuh permisif memiliki anak dengan kategori motivasi belajar yang kurang baik.

Tabel 1 Rekapitulasi Hasil Persebaran Pola Asuh Orang Tua Dan Motivasi Siswa

\begin{tabular}{ccc}
\hline Subjek & Pola asuh orang tua & Motivasi belajar siswa \\
\hline Subjek 1 & Demokratis & Kurang \\
Subjek 2 & Demokratis & Baik \\
Subjek 3 & Demokratis & Baik \\
Subjek 4 & Demokratis & Baik \\
Subjek 5 & Demokratis & Kurang \\
Subjek 6 & Demokratis & Baik \\
Subjek 7 & Demokratis & Baik \\
Subjek 8 & Demokratis & Baik \\
Subjek 9 & Demokratis & Baik \\
Subjek 10 & Demokratis & Baik \\
Subjek 11 & Permisif & Kurang \\
Subjek 12 & Permisif & Kurang \\
Subjek 13 & Demokratis & Baik \\
Subjek 14 & Demokratis & Baik \\
Subjek 15 & Demokratis & Baik \\
\hline
\end{tabular}

Berdasarkan hasil penelitian dapat diperoleh bahwa pola asuh orang tua demokratis sebesar $86,67 \%$ dan pola asuh permisif sebesar $13,33 \%$ sedangkan pola asuh otoriter tidak ditemukan. Siswa dengan motivasi baik sebesar 73,33\% dan siswa dengan motivasi kurang sebesar 26,67\%. Hasil tersebut menunjukkan bahwa orang tua MI Al-Huda lebih banyak menggunakan pola asuh demokratis, hanya dua orang tua yang menggunakan pola asuh permisif dan tidak menggunakan pola asuh otoriter. Pola asuh orang tua siswa kelas V di MI Al-Huda Kebonsari dapat dilihat pada gambar 1.

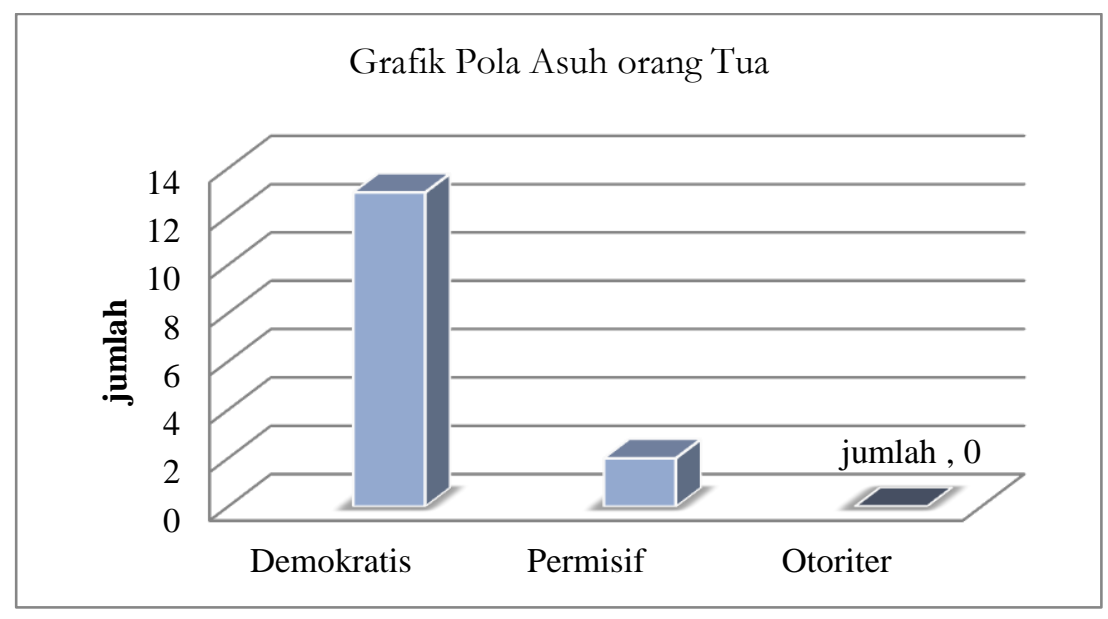

(Gambar 1 Grafik Pola Asuh Orang Tua)

2. Pola asuh orang tua terhadap motivasi belajar siswa

a. Pola Asuh Demokratis

Pola asuh demokratis ditemukan berdasarkan hasil angket dan wawancara dari 15 orang tua. Hasil tersebut menunjukkan bahwa terdapat 13 orag tua menerapkan pola asuh demokratis. Orang tua demokratis memberikan pengasuhan yang baik terhadap anak, mulai dari memberikan kontrol terhadap sikap anak, perhatian, sikap tanggap terhadap anak ketika dibutuhkan, terjalinnya komunikasi yang baik dengan anak. 
Penerapan yang dilakukan orang tua dengan pola asuh demokratis terhadap motivasi belajar mempunyai hasil yang baik untuk membangun motivasi belajar siswa. Hasil dari 13 orang tua yang menerapkan pola asuh demokratis, terdapat dua anak yang memiliki kategori motivasi belajar kurang, sedangkan lainnya masuk kategori motivasi belajar baik.

Hal ini terdapat beberapa faktor yang peneliti temukan, yang mempengaruhi motivasi belajar siswa menjadi kurang. Berikut beberapa faktor yang mempengaruhi:

1) Faktor intelegensi (kecerdasan siswa)

Pada umumnya, kecerdasan diartikan sebagai kemampuan psikofisik atau potensi dalam mereaksi rangsangan atau menyesuaikan diri dengan lingkungan melalui cara yang tepat. Intelegensi sering disebut dengan tingkat kecerdasan yang dimiliki seseorang. (Wahab, 2016). Pada penelitian ini faktor intelegnsi menjadi salah satu faktor dalam motivasi belajar siswa. Seperti yang diungkapkan orang tua siswa dalam wawancara di bawah ini:

"Selalu saya tegur mbak. Soalnya anak saya kalau tidak diingatkan tidak belajar. Apalagi dia memang sedikit kurang dalam memahami pelajaran. Tingkat kecerdasan anak kan beda-beda ya mbak, kalau adeknya malah mau belajar tanpa diingatkan. Kalau dia diajarin juga ngeyel, jadi sulit memahami” (N; Kebonsari, 2021)

Terkait pernyataan wawancara di atas, anak memiliki motivasi belajar yang kurang dikarenakan anak memiliki tingkat kecerdasan yang kurang, sulit dalam memahami materi pembelajaran. Pada kondisi saat ini pembelajaran di rumah menjadi salah satu kendala orang tua juga, ketika ada tugas dari sekolah dan anak tidak dapat memahami materi dengan baik akan membuat anak semakin sulit dalam menerima materi. Menurut Kompri dalam Emda (2017) menyatakan bahwa motivasi belajar adalah jiwa yang mengalami perkembangan, yang terpengaruh oleh kondisi fisiologis dan tingkat kematangan psikologis siswa yang dipengaruhi oleh beberapa faktor salah satu diantaranya adalah kemampuan siswa (Emda, 2017; Santoso et al, 2017). Keinginan seorang anak untuk berhasil perlu dibarengi dan diimbangi dengan kemampuan dan kecakapan siswa dalam pencapaian tujuan.

2) Pengaruh game

Terdapat dua faktor yang mempengaruhi motivasi belajar siswa, yaitu intrinsik merupakan faktor dari dalam diri seseorang dan faktor ekstrinsik yang berasal dari luar. Anak yang dengan pola asuh demokratis memiliki motivasi belajar yang kurang karena anak terlalu banyak main hp, main game bersama dengan teman-temannya. Ketika diingatkan untuk belajar biasanya anak buru-buru pergi bersama anak-anak yang lain. Hal ini diungkapkan oleh orang tua siswa yang mengungkapkan bahwa:

"Semaksimal mungkin selalu saya ingatkan ya mbak, tapi pada kenyataannya susah untuk belajar, kalau tidak. saya ingatkan pergi bermain bersama teman-temannya. Susah mbak kalau disurub belajar, karena main game di hp, kebetulan temen-temennya itu kalau sepulang sekolah atau sehabis maghrib main kesini, mabar katanya. Tapi kalau sudah malam biasanya saya suruh pulang. Kadang hpnya juga saya sita kalau dia tidak mau belajar. Saat ini kan mendekati tes ya mbak, jadi untuk hp saya kasih waktu sebentar, kalau sudah hpnya saya yang pegang.(R; Kebonsari, 2021)

Hasil wawancara tersebut menunjukkan bahwa motivasi anak untuk belajar kurang dikarenakan terlalu sering main game. Selain itu juga diperkuat dengan penelitian Nisrinafatin (2020) menyatakan bahwa terdapat pengaruh negatif antara game online dengan motivasi belajar siswa, seorang anak yang kecanduan game online akan mempengaruhi motivasi belajarnya dan jika motivasi belajarnya terganggu maka akan berpengaruh pula pada prestasi belajarnya.

Selain pengaruh game, terdapat juga pengaruh teman sebaya yang dapat mempengaruhi kegiatankegiatan anak. ketika kegiatan yang dilakukan positif maka hal itu dapat menjadi hal baik bagi perkembangan anak. Sebaliknya, jika kegiatan yang dilakukan kurang positif maka akan berdampak buruk pula bagi anak. anak akan lupa waktu untuk belajar jika sudah terlalu asyik bermain dengan teman-temannya. Sesuai dengan penelitian yang dilakukan Santi \& Khan (2019: 197) bahwa lingkungan teman-teman sebaya yang positif merupakan cara efektif yang dapat dilakukan untuk meningkatkan motivasi belajar siswa.

b. Pola asuh permisif

Open Access: https://ejournal.unma.ac.id/index.php/educatio 
Menurut (Ayun, 2017: 103) Pola asuh permisif adalah pola asuh orang tua terhadap anak yang memberikan kebebasan penuh untuk berbuat sesukanya bahkan dalam hal kurang baik sekalipun. Anak yang dengan pola asuh permisif cenderung memiliki motivasi belajar kurang, hal ini dikarenakan ketika anak tidak memiliki motivasi internal atau motivasi yang berada dalam dirinya untuk belajar dan terlebih lagi tidak ada perhatian dari orang tua, maka anak akan semakin tidak memiliki motivasi. Penerapan pola asuh yang dilakukan orang tua dapat berpengaruh pada kebiasaan belajar anak di rumah. Orang tua dengan penerapan pola asuh permisif dikarenakan orang tua sibuk dengan pekerjaannya. Orang tua yang disibukkan dengan pekerjaan membuatnya kurang meluangkan waktu dan memberikan perhatian yang lebih pada anak, sehingga cenderung acuh tak acuh dengan apa yang dilakukan anak. Sesuai dengan hasil wawancara yang dilakukan peneliti terhadap salah satu subjek dengan pola asuh permisif sebagai berikut:

"Jarang saya suruh mbak, sudah besar hehe... kalau disurub kadang-kadang malah marah mbak, jadi ya saya juga sudah capek kerja dari pada nanti malah anaknya nangis ya saya biarkan, kalau dia mau belajar ya Alhamdulillah".. (T; Banjarsari,2021)

Selain dari hasil wawancara terdapat hasil penelitian Riyadi (2021) yang menyatakan bahwa kondisi ekonomi keluarga mejadi salah satu faktor penyebab pola pengasuhan orang tua. Mereka yang diharuskan bekerja penuh waktu baik dalam mengelola warung maupun di luar rumah yang menyebabkan sangat kurangnya waktu intens bersama keluarga. Berdasarkan pernyataan-pernyataan di atas, dapat ditarik kesimpulan bahwa pola asuh yang baik dan tepat diterapkan oleh orang tua adalah pola asuh demokratis. Pola asuh demokratis memberikan perhatian terhadap kemajuan anaknya dalam belajar. Memberikan dorongan pada anak untuk selalu melakukan kegiatan-kegiatan yang positif, anak diberikan kebebasan akan tetapi masih dalam pengawasan dan kontrol yang baik dari orang tua. Diterapkannya pola asuh demoratis diharapkan dapat menjadikan siswa termotivasi dalam belajar ketika anak tidak memiliki motivasi dalam dirinya atau motivasi internal.

\section{KESIMPULAN}

Berdasarkan hasil penelitian yang telah peneliti lakukan berikut kesimpulan tentang Deskripsi Pola Asuh Orang Tua Terhadap Motivasi Belajar Peserta Didik Pada Masa Pandemi Covid-19 Kelas V Mi Al-Huda Kebonsari yakni Persebaran pola asuh orang tua terhadap motivasi belajar siswa di ri dengan presentase yang menunjukkan pola asuh demokratis sebesar $86,67 \%$ dan pola asuh permisif sebesar $13,33 \%$. Pola asuh yang dapat digunakan orang tua yaitu pola asuh demoratis, karena pola asuh ini memberikan kebebasan pada anak akan tetapi masih dalam kontrol dan batas yang wajar. Orang tua dengan pola asuh demokratis memberikan dorongan dan bimbingan dalam kegiatan anak khususnya kegiatan-kegiatan positif. Terlihat dari presentase siswa dengan motivasi baik sebesar $73,33 \%$ dan siswa dengan motivasi kurang sebesar $26,67 \%$. Hal ini menunjukkan bahwa pola asuh demokratis mempengaruhi motivasi belajar siswa.

\section{DAFTAR PUSTAKA}

Ayun, Q. (2017). Pola Asuh Orang Tua Dan Metode Pengasuhan Dalam Membentuk Kepribadian Anak. Jurnal Inovasi Pendidikan Guru Raudhatul Athfal 5(1):103-22.

Emda, A. (2018). Kedudukan motivasi belajar siswa dalam pembelajaran. Lantanida Journal, 5(2), 172-182.

Fadhilah, T. N., Handayani, D. E., \& Rofian, R. (2019). Analisis Pola Asuh Orang Tua Terhadap Motivasi Belajar Siswa. Jurnal Pedagogi dan Pembelajaran, 2(2), 249-255.

Hamidi, A. (2020). Workshop Efektivitas Pembelajaran Daring Pada Masa Pandemi Covid 19 di Prodi IKOR. Jurnal Maenpo: Jurnal Pendidikan Jasmani Kesehatan dan Rekreasi, 10(2), 109-118.

Hayati, N. (2020). Pembelajaran Jarak Jauh Selama Pandemi di Pondok Pesantren Darunajah 2 Bogor. RESIPROKAL: Jurnal Riset Sosiologi Progresif Aktual, 2(2), 151-159.

Kurniawan, S. (2016). Pendidikan karakter. Yogyakarta: Ar-Ruz Media 
Nisrinafatin, N. (2020). Pengaruh game online terhadap motivasi belajar siswa. Jurnal Edukasi Nonformal, 1(2), 135-142.

Riyadi, A. (2021). Pola Asuh Orang Tua pada Remaja Pelaku Klitih di DI Yogyakarta. Jurnal Penelitian Kesejabteraan Sosial, 20(1), 91-102.

Santi, N. N., \& Khan, R. I. (2019). Pengaruh Dukungan Teman Sebaya Terhadap Motivasi Belajar Siswa Kelas III Sekolah Dasar. JPDN Jumal Pendidikan Dasar Nusantara, 4(2), 191-198.

Santoso, B., Yuniarsih, T., Adman, A., \& Sarino, A. (2017). Pengaruh Manajemen Kelas Terhadap Motivasi Belajar Mahasiswa Program Studi Pendidikan Manajemen Perkantoran. Manajerial: Jurnal Manajemen dan Sistem Informasi, 16(2), 255-267.

Saputri, D. I., Siswanto, J., \& Sukamto, S. (2019). Pengaruh Perhatian Orang Tua dan Motivasi Terhadap Hasil Belajar. Jurnal Pedagogi dan Pembelajaran, 2(3), 369-376.

Syukmadinata, N. S. (2012). Metode Penelitian. Bandung: Remaja Rosdakarya Offset.

Umam, M. K. (2019). Penggunaan metode Jaritmatika dalam meningkatkan motivasi belajar. Awwaliyah: Jurnal Pendidikan Guru Madrasah Ibtidaiyah, 2(1), 45-68.

Utomo, L. W. (2012). Psikologi Pendidikan. Purworejo: Universitas Muhammadiyah Purworejo

Wahab, R. (2016). Psikologi Belajar. Jakarta: Rajawali Pers. 